Check for updates

Cite this: RSC Adv., 2018, 8, 16383

\title{
Lignans and isoflavonoids from the stems of Pisonia umbellifera $\uparrow$
}

\author{
Zhiguo Liu, ${ }^{a}$ Xilong Zheng, ${ }^{\mathrm{b}}$ Yanan Wang, ${ }^{\mathrm{c}}$ Mengyue Tang, ${ }^{\text {a }}$ Shilin Chen, ${ }^{\mathrm{a}}$ \\ Fangbo Zhang, ${ }^{a} \mathrm{Li} \mathrm{Li}$, (D) ${ }^{* c}$ Cun Zhang ${ }^{\star a}$ and Yi Sun (DD *a
}

Twelve new compounds including four isoflavonolignans ( $1 a / 1 b$ and $2 a / 2 b)$, two neolignans ( $3 a / 3 b)$, and six isoflavonoids (5-10), together with seven known compounds (4 and 11-16) were isolated from the stems of Pisonia umbellifera. The structures were elucidated on the basis of comprehensive spectroscopic analyses and ECD calculation methods. Compounds 1-3 were present as enantiomers that were successfully separated by chiral HPLC. Compounds $1 \mathrm{a} / 1 \mathrm{~b}$ and $2 \mathrm{a} / 2 \mathrm{~b}$ are the first examples of isoflavonolignans with a pyranoid ring linking up the isoflavonoid and the monolignol from nature. A putative biosynthetic pathway for the isoflavonolignans was deduced. The anti-inflammatory and cytotoxic activities for all compounds were evaluated

Received 14th March 2018

Accepted 25th April 2018

DOI: $10.1039 / \mathrm{c} 8 \mathrm{ra0} 2240 \mathrm{~b}$

rsc.li/rsc-advances

seven known compounds (4 and 11-16) were isolated from its stems (Fig. 1). The absolute configurations of the new isoflavonolignans (1a/1b and $\mathbf{2} \mathbf{a} / \mathbf{2} \mathbf{b})$ and neolignans $(\mathbf{3 a} / \mathbf{3} \mathbf{b})$ were elucidated by comparing their calculated and experimental electronic circular dichroism (ECD) spectra. A putative biosynthetic pathway for the isoflavonolignans was deduced. All the compounds were tested to evaluate their inhibitory effects on NO production in LPS-induced RAW 264.7 macrophages and the cytotoxic activities. Herein, we report the isolation, structure identification, and biological effects of compounds 1-16. isolation of triterpenoids, alkaloids, phenolic acids and isoflavonoids, of which some compounds exhibited antitubercular activity against Mycobacterium tuberculosis. ${ }^{\mathbf{1 , 2}}$

Isoflavonolignans are a type of lignoids, which incorporate a C6-aromatic-C3-side chain unit into an isoflavonone nucleus. Isoflavonolignans are derived from two phenylpropanoid units as they are biogenetically related to lignans and neolignans. So far, only a few isoflavonolignans, termed as benzodioxane lignoids have been isolated from Fabaceae family, which structures contain the catechol moieties in flavonoids. ${ }^{3-8}$

P. umbellifera is a common herb medicine for Li folk in China. In our investigation searching for the novel bioactive constituents from natural resource, ${ }^{\mathbf{9}, 10}$ we chose the stems of $P$. umbellifera for more detailed study. Twelve new compounds, including four isoflavonolignans $(\mathbf{1 a} / \mathbf{1} \mathbf{b}$ and $\mathbf{2 a / 2} \mathbf{b})$, two neolignans $(\mathbf{3 a} / \mathbf{3 b})$, and six isoflavonoids (5-10), together with

${ }^{a}$ Institute of Chinese Materia Medica, China Academy of Chinese Medical Sciences, Beijing 100700, PR China.E-mail: ysun@icmm.ac.cn; czhang@icmm.ac.cn

${ }^{b}$ Hainan Branch Institute of Medical Plant Development, Chinese Academy of Medical Sciences, Wanning 571100, PR China

${ }^{c}$ Institute of Materia Medica, Chinese Academy of Medical Sciences \& Peking Union Medical College, Beijing 100050, PR China.E-mail: annaleelin@imm.ac.cn

$\dagger$ Electronic supplementary information (ESI) available: 1D and 2D NMR, HR ESI-MS, UV and ECD spectra of 1-3 and 5-10. See DOI: 10.1039/c8ra02240b

\section{Results and discussion}

Compound 1 was obtained as colorless oil. The molecular formula was determined to be $\mathrm{C}_{27} \mathrm{H}_{24} \mathrm{O}_{8}$ by HRESIMS at $\mathrm{m} / \mathrm{z}$ $477.1545[\mathrm{M}+\mathrm{H}]^{+}$(calcd for $\mathrm{C}_{27} \mathrm{H}_{25} \mathrm{O}_{8}$ 477.1544). The ${ }^{1} \mathrm{H}$ NMR spectrum (Table 1 ) of 1 revealed the presence of one enolic hydroxyl group at $\delta_{\mathrm{H}} 12.54(5-\mathrm{OH})$ and one diagnostic proton of isoflavone at $\delta_{\mathrm{H}} 8.09(1 \mathrm{H}, \mathrm{s}, \mathrm{H}-2)$. The aromatic region of spectrum displayed the signals of 1,2-disubstituted moieties which were assigned to $\mathrm{H}-3^{\prime}, \mathrm{H}-4^{\prime}, \mathrm{H}-5^{\prime}$ and $\mathrm{H}-6^{\prime}$, and was consistent with the substitution pattern in ring $B$ of 6,8 dimethylisogenistein. ${ }^{2}$ The 1,3,4-trisubstituted moieties of benzene ring were also observed with the aromatic protons at $\delta_{\mathrm{H}} 6.95\left(1 \mathrm{H}, \mathrm{d}, J=7.8 \mathrm{~Hz}, \mathrm{H}-5^{\prime \prime}\right), 6.92\left(1 \mathrm{H}, \mathrm{d}, J=1.8 \mathrm{~Hz}, \mathrm{H}-2^{\prime \prime}\right)$ and $6.91\left(1 \mathrm{H}, \mathrm{dd}, J=7.8,1.8 \mathrm{~Hz}, \mathrm{H}-6^{\prime \prime}\right)$. In addition, the aliphatic region of spectrum exhibited an AMXY coupling system with the signals at $\delta_{\mathrm{H}} 5.02\left(1 \mathrm{H}, \mathrm{d}, J=9.0 \mathrm{~Hz}, \mathrm{H}-7^{\prime \prime}\right), 3.65$ $\left(1 \mathrm{H}, \mathrm{dd}, J=10.8,4.8 \mathrm{~Hz}, \mathrm{H}-9^{\prime \prime}\right), 3.55(1 \mathrm{H}, \mathrm{dd}, J=10.8,4.8 \mathrm{~Hz}$, $\left.\mathrm{H}-9^{\prime \prime}\right)$ and $2.25\left(1 \mathrm{H}, \mathrm{m}, \mathrm{H}-8^{\prime \prime}\right)$. Detailed analyses of the ${ }^{1} \mathrm{H}$ and ${ }^{13} \mathrm{C}$ NMR spectra indicated that 1 possessed the isoflavonolignan skeleton bearing a phenylpropanoid unit. The linkage of the two parts through a pyranoid ring was 


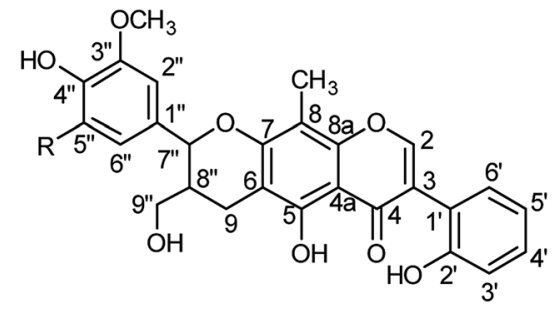

1a (7"S, 8"R) R = H $1 \mathrm{~b}\left(7^{\prime \prime} R, 8^{\prime \prime} S\right) \mathrm{R}=\mathrm{H}$ 2a (7"S, 8"R) R $=\mathrm{OCH}_{3}$ $2 \mathrm{~b}(7 " \mathrm{R}, 8$ " $\mathrm{S}) \mathrm{R}=\mathrm{OCH}_{3}$<smiles>[R2]Cc1c(O)c(C)c2occ(-c3ccccc3O)c(=O)c2c1O</smiles>

$4 \mathrm{R}=\mathrm{H}$

$5 \mathrm{R}=\mathrm{OCH}$

$6 \mathrm{R}=\mathrm{OCH}_{2} \mathrm{CH}_{3}$<smiles>[R]c1cc(O)c2c(c1)O[C@H](c1ccccc1)[C@H](O)C2=O</smiles>

$11 \mathrm{R}=\mathrm{OH}$

$12 \mathrm{R}=\mathrm{OCH}_{3}$<smiles></smiles>

15<smiles>COCC=Cc1cc(OC)c2c(c1)C(COC)C(c1ccc(O)c(OC)c1)O2</smiles>

3a $\left(7^{\prime} R, 8^{\prime} S\right)$

3b (7'S, 8'R)<smiles>[R][Z]([R])c1c([R3])c(O)c2c(=O)c(-c3ccccc3O)coc2c1O</smiles>

$7 \mathrm{R}_{1}=\mathrm{CH}_{3} \quad \mathrm{R}_{2}=\mathrm{OH} \quad \mathrm{R}_{3}=\mathrm{CHO}$ $8 \mathrm{R}_{1}=\mathrm{CHO} \mathrm{R}_{2}=\mathrm{OH} \mathrm{R}_{3}=\mathrm{CH}_{3}$ $9 \mathrm{R}_{1}=\mathrm{CH}_{3} \quad \mathrm{R}_{2}=\mathrm{OCH}_{3} \mathrm{R}_{3}=\mathrm{CH}_{2} \mathrm{OH}$ $10 \mathrm{R}_{1}=\mathrm{CH}_{2} \mathrm{OH} \mathrm{R}_{2}=\mathrm{OCH}_{3} \mathrm{R}_{3}=\mathrm{CH}_{3}$<smiles>[R]c1ccccc1[C@H]1CC(=O)c2c(O)c(C)c(O)c(C)c2O1</smiles>

$13 \mathrm{R}=\mathrm{H}$

$14 \mathrm{R}=\mathrm{OH}$<smiles>CCOC(=O)c1c(C)cc(O)cc1O</smiles>

16

Fig. 1 Structures of compounds 1-16.

confirmed by the 2D NMR spectra. Based on the HMBC correlations (Fig. 2a) from $\mathrm{CH}_{2}-9$ to $\mathrm{C}-7^{\prime \prime}\left(\delta_{\mathrm{C}} 81.0\right)$ and $\mathrm{C}-9^{\prime \prime}\left(\delta_{\mathrm{C}}\right.$ 63.4), and from $\mathrm{H}-7^{\prime \prime}$ to $\mathrm{C}-9\left(\delta_{\mathrm{C}} 21.8\right)$ and $\mathrm{C}-9^{\prime \prime}\left(\delta_{\mathrm{C}} 63.4\right)$, and the key ${ }^{1} \mathrm{H}-{ }^{1} \mathrm{H}$ COSY correlations from $\mathrm{H}-8^{\prime \prime}$ to $\mathrm{H}-7^{\prime \prime}, \mathrm{CH}_{2}-9^{\prime \prime}$ and $\mathrm{CH}_{2}-9$, respectively. The coupling constant $(J=9.0 \mathrm{~Hz})$ between $\mathrm{H}-7^{\prime \prime}$ and $\mathrm{H}-8^{\prime \prime}$ in ${ }^{1} \mathrm{H}$ NMR spectrum and the NOESY correlations (Fig. 2b) of $\mathrm{H}-8^{\prime \prime} / \mathrm{H}-6^{\prime \prime}$ and $\mathrm{H}-7^{\prime \prime} / \mathrm{CH}_{2}-9^{\prime \prime}$ suggested a trans configuration of the chiral centers on the pyranoid ring.
The absolute configuration of $\mathbf{1}$ was determined by comparing its experiment and quantum chemical calculations of the electronic circular dichroism spectra. Notably, the specific rotation of 1 displayed value of zero $(c 0.1, \mathrm{MeOH})$. Thus, chiral-phase HPLC analysis and resolution of $\mathbf{1 a}$ and $\mathbf{1 b}$ were carried out on a Daicel Chiralpak AS-H chiral column using $n$ hexane/isopropanol $(7: 3)$ as mobile phase (Fig. 3a). The absolute configurations of $\mathbf{1 a}$ and $\mathbf{1 b}$ were determined by ECD 
Table $1{ }^{1} \mathrm{H}(600 \mathrm{MHz})$ and ${ }^{13} \mathrm{C}$ NMR (150 MHz) NMR data for compounds 1-3

\begin{tabular}{|c|c|c|c|c|c|c|}
\hline \multirow[b]{2}{*}{ Position } & \multicolumn{2}{|l|}{$\mathbf{1}^{a}$} & \multicolumn{2}{|l|}{$\mathbf{2}^{b}$} & \multicolumn{2}{|l|}{$\mathbf{3}^{b}$} \\
\hline & $\delta_{\mathrm{H}}(J$ in $\mathrm{Hz})$ & $\delta_{\mathrm{C}}$ & $\delta_{\mathrm{H}}(J$ in $\mathrm{Hz})$ & $\delta_{\mathrm{C}}$ & $\delta_{\mathrm{H}}(J$ in $\mathrm{Hz})$ & $\delta_{\mathrm{C}}$ \\
\hline 1 & & & & & & 132.3 \\
\hline 2 & $8.09, \mathrm{~s}$ & 156.0 & $8.19, \mathrm{~s}$ & 157.2 & 6.98, br s & 112.2 \\
\hline 3 & & 122.9 & & 122.0 & & 145.6 \\
\hline 4 & & 182.5 & & 182.8 & & 149.4 \\
\hline $4 a$ & & 104.8 & & 106.0 & & \\
\hline 5 & & 157.2 & & 158.1 & & 130.4 \\
\hline 6 & & 106.5 & & 107.0 & 6.98, br s & 116.6 \\
\hline 7 & & 159.7 & & 160.1 & $5.59, \mathrm{~d}(16.2)$ & 134.3 \\
\hline 8 & & 103.2 & & 103.8 & $6.19, \mathrm{~m}$ & 124.3 \\
\hline $8 a$ & & 153.3 & & 154.7 & & \\
\hline \multirow[t]{2}{*}{9} & $2.74, \mathrm{dd}(17.4,10.2)$ & 21.8 & $2.73, \mathrm{dd}(16.8,10.8)$ & 22.6 & $4.08, \mathrm{dd}(6.0,1.2)$ & 74.3 \\
\hline & 2.98, dd $(17.4,5.4)$ & & 2.99, dd $(16.8,4.8)$ & & & \\
\hline $8-\mathrm{CH}_{3}$ & $2.22, \mathrm{~s}$ & 7.7 & $2.23, \mathrm{~s}$ & 7.6 & & \\
\hline $3-\mathrm{OCH}_{3}$ & & & & & $3.90, \mathrm{~s}$ & 56.8 \\
\hline 9- $\mathrm{OCH}_{3}$ & & & & & $3.39, \mathrm{~s}$ & 58.0 \\
\hline $1^{\prime}$ & & 120.4 & & 119.8 & & 134.3 \\
\hline $2^{\prime}$ & & 156.2 & & 156.8 & $6.96, \mathrm{~d}(1.8)$ & 110.6 \\
\hline $3^{\prime}$ & 7.10, dd $(7.8,1.2)$ & 119.8 & 6.94, dd $(7.8,1.2)$ & 117.2 & & 149.1 \\
\hline $4^{\prime}$ & 7.36 , ddd $(7.8,7.8,1.8)$ & 130.8 & 7.29, ddd $(7.8,7.8,1.8)$ & 132.7 & & 147.7 \\
\hline $5^{\prime}$ & 7.00, ddd $(7.8,7.8,1.2)$ & 121.3 & 6.92, ddd $(7.8,7.8,1.2)$ & 120.7 & $6.79, \mathrm{~d}(7.8)$ & 116.2 \\
\hline $6^{\prime}$ & 7.19, dd $(7.8,1.8)$ & 129.9 & 7.26, dd $(7.8,1.8)$ & 130.9 & 6.84, dd $(7.8,1.8)$ & 119.9 \\
\hline $7^{\prime}$ & & & & & $5.50, \mathrm{~d}(6.6)$ & 89.7 \\
\hline $8^{\prime}$ & & & & & $3.63, \mathrm{~m}$ & 52.7 \\
\hline \multirow[t]{2}{*}{$9^{\prime}$} & & & & & $3.65, \mathrm{~m}$ & 75.7 \\
\hline & & & & & $3.72, \mathrm{~m}$ & \\
\hline $3^{\prime}-\mathrm{OCH}_{3}$ & & & & & $3.84, \mathrm{~s}$ & 56.4 \\
\hline $9^{\prime}-\mathrm{OCH}_{3}$ & & & & & $3.41, \mathrm{~s}$ & 59.3 \\
\hline $1^{\prime \prime}$ & & 131.1 & & 131.4 & & \\
\hline $2^{\prime \prime}$ & $6.92, \mathrm{~d}(1.8)$ & 109.1 & $6.73, \mathrm{~s}$ & 105.3 & & \\
\hline $3^{\prime \prime}$ & & 147.0 & & 149.4 & & \\
\hline $4^{\prime \prime}$ & & 146.1 & & 136.7 & & \\
\hline $5^{\prime \prime}$ & $6.95, \mathrm{~d}(7.8)$ & 114.6 & & 149.4 & & \\
\hline $6^{\prime \prime}$ & 6.91, dd $(7.8,1.8)$ & 120.0 & $6.73, \mathrm{~s}$ & 105.3 & & \\
\hline $7^{\prime \prime}$ & $5.02, \mathrm{~d}(9.0)$ & 81.0 & $5.02, \mathrm{~d}(8.4)$ & 82.0 & & \\
\hline $8^{\prime \prime}$ & $2.25, \mathrm{~m}$ & 39.7 & $2.26, \mathrm{~m}$ & 40.8 & & \\
\hline \multirow[t]{2}{*}{$9^{\prime \prime}$} & 3.55, dd $(10.8,4.8)$ & 63.4 & $3.43, \mathrm{dd}(10.8,4.8)$ & 63.4 & & \\
\hline & 3.65 , dd $(10.8,4.8)$ & & 3.55, dd $(10.8,4.8)$ & & & \\
\hline $3^{\prime \prime}-\mathrm{OCH}_{3}$ & $3.92, \mathrm{~s}$ & 56.2 & $3.87, \mathrm{~s}$ & 56.8 & & \\
\hline $5^{\prime \prime}-\mathrm{OCH}_{3}$ & & & $3.87, \mathrm{~s}$ & 56.8 & & \\
\hline $5-\mathrm{OH}$ & $12.54, \mathrm{~s}$ & & & & & \\
\hline
\end{tabular}
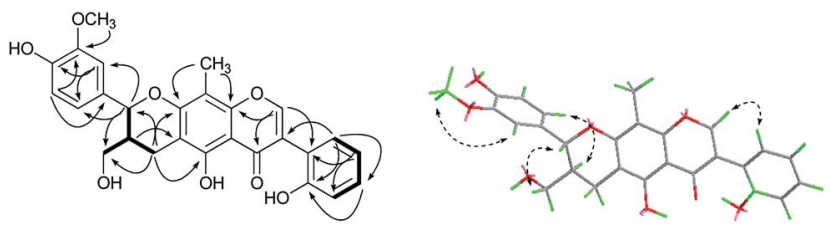

a

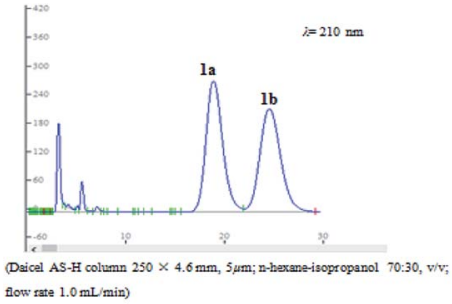

A

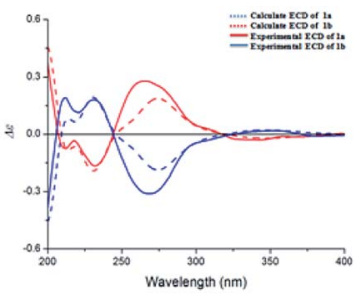

B

Fig. 2 The key $\operatorname{HMBC}(\mathrm{H} \rightarrow \mathrm{C})$ and $\operatorname{COSY}(-)(a)$, and NOESY (b) correlations of 1 .

Fig. 3 (A) Chiral-phase HPLC analytical chromatogram of 1. (B) Comparison of calculated and experimental ECD spectra of 1. 


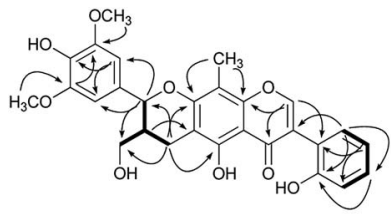

a

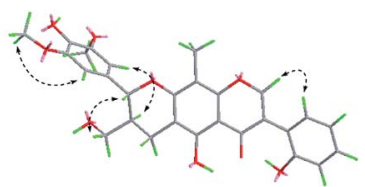

b
Fig. 4 The key $\mathrm{HMBC}(\mathrm{H} \rightarrow \mathrm{C})$ and $\operatorname{COSY}(-)(\mathrm{a})$, and NOESY (b) correlations of 2 .

calculations. The experimental ECD curves of $\mathbf{1 a}$ and $\mathbf{1 b}$ were similar to the computed curves of $\mathbf{1 a}\left(7^{\prime \prime} S\right.$ and $\left.8^{\prime \prime} R\right)$ and $\mathbf{1 b}\left(7^{\prime \prime} R\right.$ and $8^{\prime \prime} S$ ), respectively (Fig. 3b). Therefore, the structures of $\mathbf{1 a}$ and $\mathbf{1 b}$ were finally established as $\left(7^{\prime \prime} S, 8^{\prime \prime} R\right)-5$-hydroxy- $7^{\prime \prime}-\left(4^{\prime \prime}\right.$-hydroxy- $3^{\prime \prime}$ methoxyphenyl)-8" (hydroxymethyl)-3-(2'-hydroxyphenyl)-8-methyl$7^{\prime \prime}, 8^{\prime \prime}$-dihydropyrano[3,2-g]chromen- $4(9 H)$-one and $\left(7^{\prime \prime} R, 8^{\prime \prime} S\right)$ 5-hydroxy-7"-(4"-hydroxy-3"-methoxyphenyl)-8"-(hydroxymethyl)-3(2'-hydroxyphenyl)-8-methyl-7", $8^{\prime \prime}$-dihydropyrano[3,2-g] chromen$4(9 H)$-one, respectively. They are named as pisonone A and pisonone B. As far as we know, these two compounds are the first examples of isoflavonolignans featuring a pyranoid ring in nature.

Compound 2 was isolated as yellow oil, and had a molecular formula of $\mathrm{C}_{28} \mathrm{H}_{26} \mathrm{O}_{9}$ as determined by HRESIMS ion at $\mathrm{m} / \mathrm{z}$ $507.1649[\mathrm{M}+\mathrm{H}]^{+}$. The ${ }^{1} \mathrm{H}$ and ${ }^{13} \mathrm{C}$ NMR data (Table 1) showed similar signals to those of $\mathbf{1}$, and indicated that the only difference was the presence of another methoxy group in 2 . This substitution was placed at C-5" by the correlations (Fig. 4a) between the $\mathrm{OCH}_{3}\left(\delta_{\mathrm{H}} 3.87, \mathrm{~s}\right)$ and $\mathrm{C}-5^{\prime \prime}\left(\delta_{\mathrm{C}} 149.4\right)$ in the $\mathrm{HMBC}$ spectrum. The relative configurations of $\mathrm{C}-7^{\prime \prime}$ and $\mathrm{C}-8^{\prime \prime}$ were deduced from analysis of the coupling constant $(J=8.4 \mathrm{~Hz})$ and the key NOESY correlations (Fig. $4 \mathrm{~b}$ ) of $\mathrm{H}-8^{\prime \prime} / \mathrm{H}-6^{\prime \prime}$ and $\mathrm{H}-7^{\prime \prime} / \mathrm{CH}_{2}-$ $9^{\prime \prime}$, and suggested a trans relationship between them. For the same reason as $\mathbf{1}$, the racemate of $\mathbf{2 a}$ and $\mathbf{2 b}$ was obtained by the chiral-phase separation. The calculated ECD spectra were in good agreement with the experimental spectra (Fig. 5), confirming that compounds $2 \mathbf{a}$ and $\mathbf{2 b}$ possessed the $\left(7^{\prime \prime} S\right.$ and $\left.8^{\prime \prime} R\right)$ and $\left(7^{\prime \prime} R\right.$ and $8^{\prime \prime} S$ ) configurations, respectively. Thus, the planar structure of 2 were elucidated as 5-hydroxy- $7^{\prime \prime}-\left(4^{\prime \prime}\right.$-hydroxy- $3^{\prime \prime}, 5^{\prime \prime}$-dimethoxyphenyl)-8"-(hydroxymethyl)-3-(2'-hydroxyphenyl)-8-methyl- $7^{\prime \prime}, 8^{\prime \prime}-$ dihydropyrano[3,2-g]chromen-4(9H)-one. Compounds $\mathbf{2 a}$ and $\mathbf{2 b}$ are named as pisonone $\mathrm{C}$ and pisonone $\mathrm{D}$, respectively.

Compound 3 was acquired as colorless oil. On the basis of its HRESIMS at $m / z 409.1621[\mathrm{M}+\mathrm{Na}]^{+}$, its molecular formula was

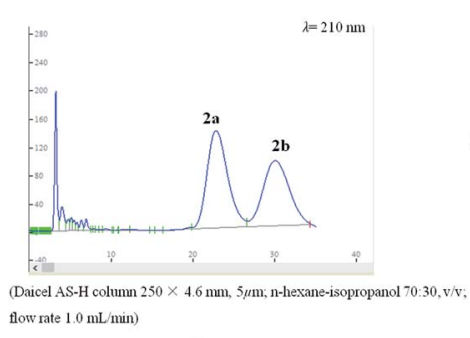

A

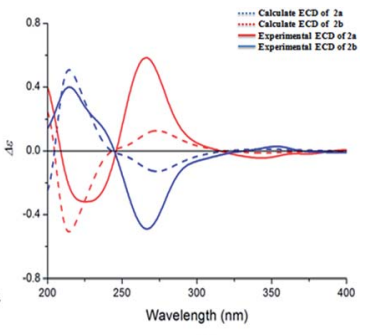

B
Fig. 5 (A) Chiral-phase HPLC analytical chromatogram of 2. (B) Comparison of calculated and experimental ECD spectra of 2.
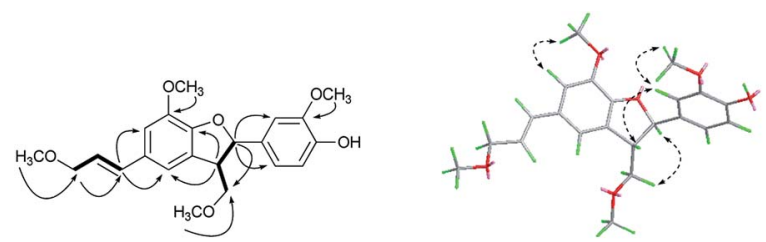

a

b

Fig. 6 The key $\operatorname{HMBC}(\mathrm{H} \rightarrow \mathrm{C})$ and $\operatorname{COSY}(-)(a)$, and NOESY (b) correlations of 3 .

determined as $\mathrm{C}_{22} \mathrm{H}_{26} \mathrm{O}_{6}$. The ${ }^{1} \mathrm{H}$ NMR spectrum (Table 1) showed two groups of aromatic protons at $\delta_{\mathrm{H}} 6.98(2 \mathrm{H}, \mathrm{br} \mathrm{s}, \mathrm{H}-2$ and $\mathrm{H}-6), 6.96\left(1 \mathrm{H}, \mathrm{d}, J=1.8 \mathrm{~Hz}, \mathrm{H}-2^{\prime}\right), 6.84(1 \mathrm{H}, \mathrm{dd}, J=7.8$, $\left.1.8 \mathrm{~Hz}, \mathrm{H}-6^{\prime}\right)$ and $6.79\left(1 \mathrm{H}, \mathrm{d}, J=7.8 \mathrm{~Hz}, \mathrm{H}-5^{\prime}\right)$ corresponding to 1,3,4,5-tetrasubstituted and 1,3,4-trisubstituted phenyl moieties. In addition, two trans olefinic protons at $\delta_{\mathrm{H}} 5.59(1 \mathrm{H}, \mathrm{d}, J=$ $16.2 \mathrm{~Hz}, \mathrm{H}-7)$ and $6.19(1 \mathrm{H}, \mathrm{m}, \mathrm{H}-8)$, one oxymethine protons at $\delta_{\mathrm{H}} 5.50\left(1 \mathrm{H}, \mathrm{d}, J=6.6 \mathrm{~Hz}, \mathrm{H}-7^{\prime}\right)$, two oxymethylene protons at $\delta_{\mathrm{H}}$ $4.08(2 \mathrm{H}, \mathrm{dd}, J=6.0,1.2 \mathrm{~Hz}, \mathrm{H}-9), 3.72\left(1 \mathrm{H}, \mathrm{m}, \mathrm{H}-9^{\prime}\right)$ and 3.65 $\left(1 \mathrm{H}, \mathrm{m}, \mathrm{H}-9^{\prime}\right)$ were observed. The ${ }^{13} \mathrm{C}$ NMR and HSQC spectra revealed the presence of 22 carbon resonances, including 12 phenyl carbons, 2 olefinic carbon, 4 methoxy carbons, and 4 aliphatic carbons. Comparison of the NMR data with those of the dehydrodiconiferyl alcohol, ${ }^{11}$ they had a similar planar structure except for the presence of a methoxy group in 3 . The methoxy group was determined at C-9' by the HMBC correlations (Fig. 6a). According to the $J_{7^{\prime}, 8^{\prime}}$ value $(6.6 \mathrm{~Hz})$ and key NOESY correlations (Fig. 6b) of $\mathrm{H}-8^{\prime} / \mathrm{H}-2^{\prime}$ and $\mathrm{H}-7^{\prime} / \mathrm{CH}_{2}-9^{\prime}$, the relative configuration of $\mathrm{C}-7^{\prime}$ and $\mathrm{C}-8^{\prime}$ was suggested to be trans. The racemate of $\mathbf{3 a}$ and $\mathbf{3} \mathbf{b}$ was also separated by chiral HPLC, and the absolute configuration of their furan rings was identified by comparing of their experimental and calculated ECD data (Fig. 7). Thus, compounds $\mathbf{3 a}$ and $\mathbf{3 b}$ were determined as shown and named as $\left(7^{\prime} R, 8^{\prime} S\right)$-9'-methoxy-dehydrodiconiferyl alcohol and $\left(7^{\prime} S, 8^{\prime} R\right)-9^{\prime}$-methoxy-dehydrodiconiferyl alcohol.

Compound 5 was obtained as yellow needles. It showed a quasi-molecular ion peak at $\mathrm{m} / \mathrm{z} 329.1020[\mathrm{M}+\mathrm{H}]^{+}$, corresponding to the molecular formula of $\mathrm{C}_{18} \mathrm{H}_{16} \mathrm{O}_{6}$. The 1D NMR spectra (Table 2) displayed similar substitution pattern as $\mathbf{4}$, the major difference between the two compounds was the methyl etherification at C-9 in 5. The above conclusion was confirmed by the HMBC correlations of $\mathrm{OCH}_{3}$ with C-9 $\left(\delta_{\mathrm{C}} 67.8\right)$. Thus, the structure of 5 was assigned as $5,7,2^{\prime}$-trihydroxy-6-methylene-8methyl-9-methoxyisoflavone, and named as pisonone $\mathrm{E}$.
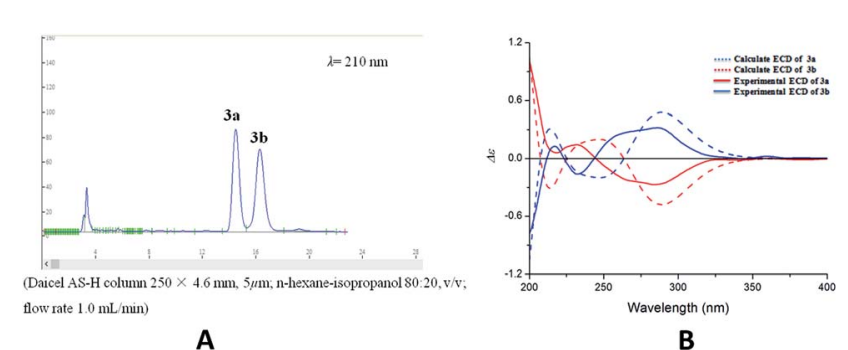

Fig. 7 (A) Chiral-phase HPLC analytical chromatogram of 3. (B) Comparison of calculated and experimental ECD spectra of 3 . 
Table $2{ }^{1} \mathrm{H}\left(600 \mathrm{MHz}, \mathrm{CDCl}_{3}\right)$ and ${ }^{13} \mathrm{C}\left(150 \mathrm{MHz}, \mathrm{CDCl}_{3}\right)$ NMR data for compounds 5-7

\begin{tabular}{|c|c|c|c|c|c|c|}
\hline \multirow[b]{2}{*}{ Position } & \multicolumn{2}{|l|}{5} & \multicolumn{2}{|l|}{6} & \multicolumn{2}{|l|}{7} \\
\hline & $\delta_{\mathrm{H}}(J$ in $\mathrm{Hz})$ & $\delta_{\mathrm{C}}$ & $\delta_{\mathrm{H}}(J$ in $\mathrm{Hz})$ & $\delta_{\mathrm{C}}$ & $\delta_{\mathrm{H}}(J$ in $\mathrm{Hz})$ & $\delta_{\mathrm{C}}$ \\
\hline 2 & $8.09, \mathrm{~s}$ & 156.0 & $8.08, \mathrm{~s}$ & 155.9 & $8.12, \mathrm{~s}$ & 154.8 \\
\hline 3 & & 123.1 & & 123.0 & & 125.2 \\
\hline 4 & & 182.5 & & 182.4 & & 181.3 \\
\hline $4 a$ & & 104.6 & & 104.5 & & 104.5 \\
\hline 5 & & 156.5 & & 156.3 & & 165.4 \\
\hline 6 & & 105.6 & & 105.9 & & 109.9 \\
\hline 7 & & 162.4 & & 162.5 & & 168.2 \\
\hline 8 & & 103.5 & & 103.4 & & 102.5 \\
\hline $8 a$ & & 154.9 & & 154.8 & & 158.2 \\
\hline 9 & $4.90, \mathrm{~s}$ & 67.8 & $4.92, \mathrm{~s}$ & 65.9 & & \\
\hline $6-\mathrm{CH}_{3}$ & & & & & $2.16, \mathrm{~s}$ & 6.7 \\
\hline 8-CHO & & & & & $10.37, \mathrm{~s}$ & 189.8 \\
\hline $8-\mathrm{CH}_{3}$ & $2.25, \mathrm{~s}$ & 7.4 & $2.24, \mathrm{~s}$ & 7.3 & & \\
\hline 9- $\mathrm{OCH}_{3}$ & $3.53, \mathrm{~s}$ & 58.9 & & & & \\
\hline 9- $\mathrm{OCH}_{2} \mathrm{CH}_{3}$ & & & $3.70, \mathrm{dd}(14.4,7.2)$ & 67.2 & & \\
\hline 9- $\mathrm{OCH}_{2} \mathrm{CH}_{3}$ & & & $1.33, \mathrm{t}(7.2)$ & 15.1 & & \\
\hline $1^{\prime}$ & & 120.2 & & 120.2 & & 119.0 \\
\hline $2^{\prime}$ & & 156.2 & & 156.1 & & 155.9 \\
\hline $3^{\prime}$ & 7.10, dd $(7.8,1.2)$ & 119.8 & 7.10, dd $(7.8,1.2)$ & 119.8 & 7.11, dd $(7.8,1.2)$ & 119.9 \\
\hline $4^{\prime}$ & 7.36, ddd $(7.8,7.8,1.8)$ & 130.8 & 7.36, ddd $(7.8,7.8,1.8)$ & 130.8 & 7.40, ddd $(7.8,7.8,1.8)$ & 131.4 \\
\hline $5^{\prime}$ & 7.00, ddd $(7.8,7.8,1.2)$ & 121.3 & 7.00, ddd $(7.8,7.8,1.2)$ & 121.3 & 7.04 , ddd $(7.8,7.8,1.2)$ & 121.6 \\
\hline $6^{\prime}$ & 7.18, dd $(7.8,1.8)$ & 129.9 & 7.17, dd $(7.8,1.8)$ & 129.9 & 7.19, dd $(7.8,1.8)$ & 130.2 \\
\hline $5-\mathrm{OH}$ & $12.59, \mathrm{~s}$ & & $12.58, \mathrm{~s}$ & & & \\
\hline 7-OH & 9.33 , br s & & 9.62, br s & & & \\
\hline $2^{\prime}-\mathrm{OH}$ & 8.22 , br s & & 8.25 , br s & & & \\
\hline
\end{tabular}

Compound 6 was isolated as a yellow powder with the molecular formula of $\mathrm{C}_{19} \mathrm{H}_{18} \mathrm{O}_{6}$ (HRESIMS and NMR data). It has more 14 mass units than that of compound 5. The ${ }^{1} \mathrm{H}$ and ${ }^{13} \mathrm{C}$ NMR data of $\mathbf{6}$ (Table 2) were similar to those of $\mathbf{5}$, indicating that the only difference between the two structures was the presence of an additional oxymethylene group in 6. The oxymethylene group was assigned to $\mathrm{C}-9$ by the $\mathrm{HMBC}$ correlations from $\mathrm{OCH}_{2} \mathrm{CH}_{3}-9$ to $\mathrm{C}-9\left(\delta_{\mathrm{C}} 65.9\right)$ and $\mathrm{OCH}_{2} \mathrm{CH}_{3}-9\left(\delta_{\mathrm{C}} 15.1\right)$, as well as the ${ }^{1} \mathrm{H}-{ }^{1} \mathrm{H}$ COSY correlations from $\mathrm{OCH}_{2} \mathrm{CH}_{3}-9\left(\delta_{\mathrm{H}} 3.70\right)$ to $\mathrm{OCH}_{2} \mathrm{CH}_{3}-9\left(\delta_{\mathrm{H}} 1.33\right)$. Thus, the structure of 6 was defined as 5,7,2'-trihydroxy-6-methylene-8-methyl-9-ethoxyisoflavone, and named as pisonone $\mathrm{F}$.

Compounds 7 and 8 were obtained as colorless oil, and determined to have the same molecular formula $\mathrm{C}_{17} \mathrm{H}_{12} \mathrm{O}_{6}$ by ${ }^{13} \mathrm{C}$ NMR and HRESIMS data. Extensive analysis of 1D and 2D NMR data (Tables 2 and 3) indicated that their structures were similar to that of 4 , and the major differences were the presence of methyl groups at C- 6 or C-8, replaced by an aldehyde group. The position of the aldehyde groups were located at C-8 in 7 and at C6 in 8, respectively, which were elucidated by the HMBC correlations from $\mathrm{CHO}-8$ to $\mathrm{C}-7\left(\delta_{\mathrm{C}} 168.2\right)$ and $\mathrm{C}-8 a\left(\delta_{\mathrm{C}} 158.2\right)$ in 7 , as well as the HMBC correlations from CHO- 6 to $\mathrm{C}-5\left(\delta_{\mathrm{C}} 166.0\right)$ and C-7 $\left(\delta_{\mathrm{C}} 166.2\right)$ in 8. Thus, the structures of 7 and 8 were established as 5,7,2'-trihydroxy-6-methyl-8-aldehydeisoflavone and $5,7,2^{\prime}$-trihydroxy-6-aldehyde-8-methylisoflavone, and named as pisonone $\mathrm{G}$ and pisonone $\mathrm{H}$, respectively.

Compounds 9 and 10 were isolated as colorless oil. Its molecular formula was $\mathrm{C}_{18} \mathrm{H}_{16} \mathrm{O}_{6}$ as deduced by their HRESIMS and NMR data.
Comparison of their ${ }^{1} \mathrm{H}$ and ${ }^{13} \mathrm{C}$ NMR data (Table 3) suggested that they displayed similar structure to that of $\mathbf{4}$, the differences between them were the presence of a hydroxymethyl group and a methoxy group in 9 and 10. The $\mathrm{HMBC}$ correlations from $\mathrm{CH}_{2} \mathrm{OH}-8$ to C-7 $\left(\delta_{\mathrm{C}}\right.$ 164.6) and $\mathrm{C}-8 a\left(\delta_{\mathrm{C}} 153.5\right)$ in 9 and the correlations from $\mathrm{CH}_{2} \mathrm{OH}-6$ to $\mathrm{C}-5\left(\delta_{\mathrm{C}} 158.4\right)$ and $\mathrm{C}-7\left(\delta_{\mathrm{C}} 163.7\right)$ in 10 indicated that the hydroxymethyl groups were placed at C-8 in 9 and at C-6 in 10, respectively. The methoxy groups in both $\mathbf{9}$ and $\mathbf{1 0}$ were located at C-7 by the relevant HMBC and NOESY experiments. Thus, the structures of $\mathbf{9}$ and 10 were deduced to be 5,2'-dihydroxy-6-methyl-7-methoxy-8hydroxymethylisoflavone and 5,2'-dihydroxy-6-hydroxymethyl-7methoxy-8-methylisoflavone, and named as pisonone I and pisonone $\mathrm{J}$.

The seven known compounds were identified as 6,8-dimethylisogenistein (4), ${ }^{2}$ pinobanksin (11), ${ }^{12}$ alpinone $(\mathbf{1 2}),{ }^{13}$ desmethoxymatteucinol (13), ${ }^{14}$ matteucin (14), ${ }^{15}$ ozoroalide (15), ${ }^{\mathbf{1 6}}$ and ethyl orsellinate $(\mathbf{1 6})^{\mathbf{1 7}}$ by comparing their spectroscopic data with the literature values.

The analysis of the biosynthetic pathway of the isoflavonolignans $(\mathbf{1 a} / \mathbf{1} \mathbf{b}, \mathbf{2 a} / \mathbf{2} \mathbf{b})$ revealed that the structures were formed via phenylpropanoid pathway transforming phenylalanine into 4-coumaroyl-CoA, which extended the isoflavone and monolignol pathways. The condensation of three malonyl-CoAs and one 4-coumaroyl-CoA produced the isoflavone fragment $\mathbf{A}$, which was methylated on the C- 6 and C- 8 of the B-ring. The methyl group at C-6 was then oxidized to yield fragment $\mathbf{B}$, which was the precursor of the isoflavonoid part for compounds 1 and 2. On the other hand, coniferyl alcohol (fragment C) 
Table $3{ }^{1} \mathrm{H}\left(600 \mathrm{MHz}, \mathrm{CDCl}_{3}\right)$ and ${ }^{13} \mathrm{C}\left(150 \mathrm{MHz}, \mathrm{CDCl}_{3}\right)$ NMR data for compounds 8-10

\begin{tabular}{|c|c|c|c|c|c|c|}
\hline \multirow[b]{2}{*}{ Position } & \multicolumn{2}{|l|}{8} & \multicolumn{2}{|l|}{9} & \multicolumn{2}{|l|}{10} \\
\hline & $\delta_{\mathrm{H}}(J$ in $\mathrm{Hz})$ & $\delta_{\mathrm{C}}$ & $\delta_{\mathrm{H}}(J$ in $\mathrm{Hz})$ & $\delta_{\mathrm{C}}$ & $\delta_{\mathrm{H}}(J$ in $\mathrm{Hz})$ & $\delta_{\mathrm{C}}$ \\
\hline 3 & & 123.6 & & 123.7 & & 123.6 \\
\hline 4 & & 182.7 & & 182.8 & & 183.0 \\
\hline $4 a$ & & 104.0 & & 107.6 & & 107.9 \\
\hline 7 & & 166.2 & & 164.6 & & 163.7 \\
\hline 8 & & 103.7 & & 112.5 & & 110.0 \\
\hline $8 a$ & & 159.2 & & 153.5 & & 154.9 \\
\hline 6-CHO & $10.42, \mathrm{~s}$ & 193.0 & & & & \\
\hline 6- $\mathrm{CH}_{2} \mathrm{OH}$ & & & & & $4.84, \mathrm{~s}$ & 62.6 \\
\hline $6-\mathrm{CH}_{3}$ & & & $2.26, \mathrm{~s}$ & 8.7 & & \\
\hline $2^{\prime}$ & & 155.9 & & 156.1 & & 155.9 \\
\hline $3^{\prime}$ & $7.11, \mathrm{dd}(7.8,1.2)$ & 119.8 & $7.11, \mathrm{dd}(7.8,1.2)$ & 119.8 & $7.11, \mathrm{dd}(7.8,1.2)$ & 119.8 \\
\hline $4^{\prime}$ & 7.39, ddd $(7.8,7.8,1.8)$ & 131.3 & 7.38 , ddd $(7.8,7.8,1.8)$ & 131.0 & 7.38, ddd $(7.8,7.8,1.8)$ & 131.0 \\
\hline $5^{\prime}$ & 7.03, ddd $(7.8,7.8,1.2)$ & 121.6 & 7.02, ddd $(7.8,7.8,1.2)$ & 121.5 & 7.02, ddd $(7.8,7.8,1.2)$ & 121.5 \\
\hline $6^{\prime}$ & 7.19, dd $(7.8,1.8)$ & 130.0 & 7.17, dd $(7.8,1.8)$ & 130.1 & 7.18, dd $(7.8,1.8)$ & 130.0 \\
\hline $5-\mathrm{OH}$ & & & $12.62, \mathrm{~s}$ & & $12.58, \mathrm{~s}$ & \\
\hline
\end{tabular}

formed the lignin moiety. Finally, the biosynthesis of isoflavonolignans $(\mathbf{1} \mathbf{a} / \mathbf{1} \mathbf{b}$ and $\mathbf{2 a} / \mathbf{2} \mathbf{b})$ occurred by the elimination of water and cyclization between flavonoid precursor and coniferyl alcohol (Fig. 8).

All compounds were evaluated for their in vitro inhibitory effects on LPS-induced NO production in macrophages (Table 4). Among them, compounds 13 and 15 exhibited moderate inhibitory activities with $\mathrm{IC}_{50}$ values of 33.15 and $11.30 \mu \mathrm{M}$, respectively.

The cytotoxic activities of compounds 1-16 were evaluated against human chronic myelogenous leukemia (K562) and human lung carcinoma (A549) cell lines that present adherent and non-adherent cancer cell type models (Table 5). Compound 5 exhibited the strongest activity against K562 cell line among all the isolates, whereas some of the compounds showed moderate activities against both cell lines. Compounds 1-3 were proved to be inactive in both assays.

\section{Conclusions}

Pisonia umbellifera is a folk medicine in Hainan province of China. In our investigation searching for novel bioactive constituents from natural source, twelve new compounds along with seven known ones were isolated from $P$. umbellifera. Compounds $\mathbf{1}$ and $\mathbf{2}$ are the first examples of isoflavonolignans featuring a pyranoid ring in nature, which enriches the structural types of this lignans. The anti-inflammatory and cytotoxic activities of all compounds were evaluated. Compounds $\mathbf{1 3}$ and $\mathbf{1 5}$ exhibited moderate in vitro anti-inflammatory activities, and compound $\mathbf{5}$ exhibited the strongest activity against K562 cell line among all the isolates.

\section{Experimental}

\section{General experimental procedures}

Optical rotations were measured with a Perkin-Elmer 241 polarimeter. The UV spectra were conducted on a Shimadzu UV2201 spectrometer. ECD spectra were recorded on a JASCO J-815 spectrometer. HRESIMS were recorded on Agilent AccurateMass-Q-TOF MS 6520 system equipped with electrospray ionization (ESI) source. NMR spectra were recorded on a Bruker AV600 NMR spectrometer using TMS as an internal standard. The chromatographic silica gel (200-300 mesh) and polyamide (100-200 mesh) were purchased from Qingdao Marine Chemical Factory (Qingdao, China) and ODS $(50 \mu \mathrm{m})$ was produced by YMC Co. LTD., Kyoto, Japan. Sephadex LH-20 was purchased from GE Healthcare. RP-HPLC separations were conducted using a Shimadzu LC-20AT liquid chromatograph with a YMCPACK ODS-A column $(250 \times 10 \mathrm{~mm}, 5 \mu \mathrm{m})$ and Knauer K-2600 UV detector. Chiral separation was conducted in a Daicel AS-H column $(250 \times 4.6 \mathrm{~mm}, 5 \mu \mathrm{m})$ from Daicel Chemical Industries, Ltd. (Japan). TLC spots were visualized under UV light and by dipping into $10 \% \mathrm{H}_{2} \mathrm{SO}_{4}$ in EtOH followed by heating. RAW 264.7 cells, human chronic myelogenous leukemia (K562) and human lung carcinoma (A549) cell lines were obtained from National infrastructure of cell line resource.

\section{Plant material}

The plant material was collected in Hainan province, China, and identified by Professor Xilong Zheng, Hainan Branch Institute of Medical Plant Development, Chinese Academy of Medical Sciences, Wanning, China. The voucher specimen (GM20170121) was deposited in the Institute of Chinese Materia 
<smiles>[NH3+]C([O-])C(CC1CCCC1)[N+](=O)[O-]</smiles>

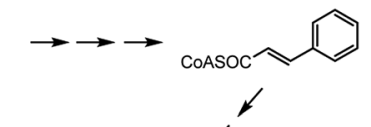
$+\quad 3 \mathrm{CH}_{2} \mathrm{COCOA}$

Medica, China Academy of Chinese Medical Sciences, Beijing, China.

\section{Extraction and isolation}

The dried stems of $P$. umbellifera $(5 \mathrm{~kg})$ were extracted with $95 \%$ EtOH $(3 \times 20 \mathrm{~L})$ three times $(3 \mathrm{~h}, 2 \mathrm{~h}, 1 \mathrm{~h})$ under reflux. The EtOH extracts were concentrated to afford a crude extract (500 g), which was suspended in $\mathrm{H}_{2} \mathrm{O}$ and partitioned successively with petroleum ether, $\mathrm{CH}_{2} \mathrm{Cl}_{2}$ and EtOAc. The $\mathrm{CH}_{2} \mathrm{Cl}_{2}$ extract (35 g) was subjected to column chromatography (CC) on silica gel using a gradient system of increasing polarity of petroleum ether-acetone (100:0-0:100, v/v) to give 10 fractions (Fr. A-Fr. J). Fr. D $(3.2 \mathrm{~g})$ was chromatographed over $\mathrm{RP}^{-\mathrm{C}_{18}}$ silica gel eluted with $\mathrm{MeOH}-\mathrm{H}_{2} \mathrm{O}$ (from 60 to $80 \%$ ) to give three fractions Fr. D1-Fr. D3. Fr. D1 (200 mg) was subjected to Sephadex LH-20 CC eluted with $\mathrm{MeOH}$ to give two subfractions (Fr. D1A-Fr. D1B). Fr. D1A was repeatedly recrystallized in petroleum etheracetone $(1: 1)$ to give $3(2.6 \mathrm{mg})$ and $15(2.1 \mathrm{mg})$. Fr. D1B was further purified by a semi-preparative HPLC $\left(\mathrm{CH}_{3} \mathrm{CN}-\mathrm{H}_{2} \mathrm{O}\right.$, $75: 25)$ to afford $5(3.4 \mathrm{mg}), 6(8.9 \mathrm{mg})$ and $13(2.9 \mathrm{mg})$. Fr. F $(2.0$ g) was divided into subfractions Fr. F1 and Fr. F2 by reversedphase ODS CC eluted with $\mathrm{MeOH}-\mathrm{H}_{2} \mathrm{O}$ (from 50 to $80 \%$ ). 2
Table 4 Inhibitory effect of compounds 1-16 on LPS-induced NO production in macrophages ${ }^{a}$

\begin{tabular}{llll}
\hline Compounds & $\mathrm{IC}_{50} \pm \mathrm{SD}^{b}(\mu \mathrm{M})$ & Compounds & $\mathrm{IC}_{50} \pm \mathrm{SD}(\mu \mathrm{M})$ \\
\hline $\mathbf{1 a}$ & $>100$ & $\mathbf{8}$ & $>100$ \\
$\mathbf{1 b}$ & $>100$ & $\mathbf{9}$ & $>100$ \\
$\mathbf{2 a}$ & $>100$ & $\mathbf{1 0}$ & $>100$ \\
$\mathbf{2 b}$ & $>100$ & $\mathbf{1 1}$ & $53.91 \pm 0.45$ \\
$\mathbf{3 a}$ & $>100$ & $\mathbf{1 2}$ & $84.32 \pm 0.72$ \\
3b & $>100$ & $\mathbf{1 3}$ & $33.15 \pm 1.18$ \\
$\mathbf{4}$ & $73.90 \pm 0.24$ & $\mathbf{1 4}$ & $>100$ \\
$\mathbf{5}$ & $73.13 \pm 0.66$ & $\mathbf{1 5}$ & $11.30 \pm 0.87$ \\
$\mathbf{6}$ & $>100$ & $\mathbf{1 6}$ & $52.09 \pm 1.21$ \\
7 & $>100$ & Resveratrol & $40.20 \pm 0.94$
\end{tabular}

${ }^{a}$ Resveratrol was used as positive control. Results are presented as the means $\pm \mathrm{SD}(n=3) .{ }^{b}$ Concentration necessary for $50 \%$ inhibition $\left(\mathrm{IC}_{50}\right)$.

(2.4 mg) and $12(3.7 \mathrm{mg})$ were obtained from Fr. F1 using Sephadex LH-20 column (MeOH). Fr. F2 was separated by semipreparative HPLC on an ODS column $\left(\mathrm{CH}_{3} \mathrm{CN}-\mathrm{H}_{2} \mathrm{O}, 55: 45\right)$ to obtain compounds $\mathbf{9}(2.6 \mathrm{mg})$ and $\mathbf{1 0}(3.0 \mathrm{mg})$. Fr. $\mathrm{H}(2.5 \mathrm{~g})$ was purified on a polyamide column, eluted with a gradient of $\mathrm{MeOH}-\mathrm{H}_{2} \mathrm{O}$ from $2: 8$ to $9: 1$, to yield four subfractions (Fr. H1-Fr. H4). Fr. H1 (320 mg) was subjected to a silica gel column eluted with petroleum ether-EtOAc (from $10: 1$ to $2: 1$ ), followed by recrystallization from $\mathrm{MeOH}$ to give $\mathbf{4}(4.1 \mathrm{mg})$ and $\mathbf{1 1}$ (3.5 mg). 1 ( $2.3 \mathrm{mg})$ and $\mathbf{1 4}(3.2 \mathrm{mg})$ was isolated from Fr. H2 by a Sephadex LH-20 column chromatography $\left(\mathrm{CH}_{2} \mathrm{Cl}_{2}-\mathrm{MeOH}\right.$, $1: 1)$. Fr. $\mathrm{H} 4$ was further purified by using semi-preparative HPLC $\left(\mathrm{CH}_{3} \mathrm{CN}-\mathrm{H}_{2} \mathrm{O}, 65: 15\right)$ to yield $7(2.6 \mathrm{mg}), 8(2.4 \mathrm{mg})$ and $16(4.6 \mathrm{mg})$.

Pisonones A (1a) and B (1b). Colorless oil; $[\alpha]_{\mathrm{D}}^{25}$ (undetected); UV $(\mathrm{MeOH}) \lambda_{\max }(\log \varepsilon) 237(0.36) \mathrm{nm} ; 271(0.12) \mathrm{nm}$; ECD $(\mathrm{MeOH}) \lambda_{\max }(\Delta \varepsilon) 1 \mathrm{a}, 232(-0.17)$ and $266(+0.28) \mathrm{nm} ; \mathbf{1 b}, 231$ $(+0.18)$ and $268(-0.31) \mathrm{nm} ;{ }^{1} \mathrm{H}$ NMR $\left(600 \mathrm{MHz}, \mathrm{CDCl}_{3}\right)$ and ${ }^{13} \mathrm{C}$ NMR $\left(150 \mathrm{MHz}, \mathrm{CDCl}_{3}\right)$ data, see Table 1; HRESIMS $\mathrm{m} / \mathrm{z}$ $477.1545[\mathrm{M}+\mathrm{H}]^{+}$(calcd for $\mathrm{C}_{27} \mathrm{H}_{25} \mathrm{O}_{8}, 477.1544$ ).

Pisonones C (2a) and $\mathbf{D}(\mathbf{2 b})$. Yellow oil; $[\alpha]_{\mathrm{D}}^{25}$ (undetected); UV (MeOH) $\lambda_{\max }(\log \varepsilon) 239(0.47) \mathrm{nm} ; 270(0.11) \mathrm{nm} ; \mathrm{ECD}$ $(\mathrm{MeOH}) \lambda_{\max }(\Delta \varepsilon) 2 \mathrm{a}, 231(-0.33)$ and $266(+0.64) \mathrm{nm} ; 2 \mathbf{b}, 212$ $(+0.48)$ and $267(-0.53) \mathrm{nm} ;{ }^{1} \mathrm{H}$ NMR $(600 \mathrm{MHz}, \mathrm{MeOD})$ and ${ }^{13} \mathrm{C}$ NMR (150 MHz, MeOD) data, see Table 1; HRESIMS $\mathrm{m} / \mathrm{z}$ $507.1649[\mathrm{M}+\mathrm{H}]^{+}$(calcd for $\mathrm{C}_{28} \mathrm{H}_{27} \mathrm{O}_{9}, 507.1650$ ).

9'-Methoxy-dehydrodiconiferyl alcohol (3a and 3b). Colorless oil; $[\alpha]_{\mathrm{D}}^{25}$ (undetected); UV (MeOH) $\lambda_{\max }(\log \varepsilon) 240(0.21) \mathrm{nm}$; $280(0.48) \mathrm{nm} ; \mathrm{ECD}(\mathrm{MeOH}) \lambda_{\max }(\Delta \varepsilon) 3 \mathrm{a}, 232(+0.14)$ and 284 $(-0.27) \mathrm{nm} ; 3 \mathbf{b}, 233(-0.20)$ and $287(+0.29) \mathrm{nm} ;{ }^{1} \mathrm{H}$ NMR $(600$ $\mathrm{MHz}, \mathrm{MeOD})$ and ${ }^{13} \mathrm{C}$ NMR (150 MHz, MeOD) data, see Table 1; HRESIMS $\mathrm{m} / \mathrm{z} 409.1621[\mathrm{M}+\mathrm{Na}]^{+}$(calcd for $\mathrm{C}_{22} \mathrm{H}_{26} \mathrm{NaO}_{6}$, 409.1622).

Pisonone E (5). Yellow needles; UV (MeOH) $\lambda_{\max }(\log \varepsilon) 222$ (0.75) nm; $267(0.15) \mathrm{nm} ;{ }^{1} \mathrm{H}$ NMR $\left(600 \mathrm{MHz}, \mathrm{CDCl}_{3}\right)$ and ${ }^{13} \mathrm{C}$ NMR $\left(150 \mathrm{MHz}, \mathrm{CDCl}_{3}\right)$ data, see Table 2; HRESIMS $\mathrm{m} / \mathrm{z}$ $329.1020[\mathrm{M}+\mathrm{H}]^{+}$(calcd for $\left.\mathrm{C}_{18} \mathrm{H}_{17} \mathrm{O}_{6}, 329.1020\right)$. 
Table 5 Cytotoxicity of compounds 1-16 $\left(\mathrm{IC}_{50} \text { in } \mu \mathrm{M}\right)^{a}$ on $\mathrm{A} 549$ and K562 cells

\begin{tabular}{llllll}
\hline Compounds & A549 & K562 & Compounds & A549 & K562 \\
\hline $\mathbf{1 a}$ & - & - & $\mathbf{1 0}$ & - & - \\
$\mathbf{2 a}$ & - & - & $\mathbf{1 1}$ & 36.8 & 18.4 \\
$\mathbf{3 a}$ & - & - & $\mathbf{1 2}$ & 35.0 & 17.5 \\
$\mathbf{4}$ & 33.6 & 16.8 & $\mathbf{1 3}$ & - & 17.6 \\
$\mathbf{5}$ & 13.6 & 6.7 & $\mathbf{1 4}$ & - & 16.7 \\
$\mathbf{6}$ & 13.1 & 14.6 & $\mathbf{1 5}$ & 34.2 & 7.5 \\
7 & - & 35.3 & $\mathbf{1 6}$ & - & 11.2 \\
$\mathbf{8}$ & - & - & Adriamycin & 2.9 & 2.0 \\
$\mathbf{9}$ & - & - & & & \\
${ }^{a}$ & \multicolumn{7}{l}{ Presents a pair of enantiomers; “-” presents IC } \\
50
\end{tabular}

Pisonone F (6). Yellow powder; UV $(\mathrm{MeOH}) \lambda_{\max }(\log \varepsilon) 232$ (0.11) nm; $268(0.22) \mathrm{nm} ;{ }^{1} \mathrm{H}$ NMR (600 MHz, $\mathrm{CDCl}_{3}$ ) and ${ }^{13} \mathrm{C}$ NMR (150 MHz, $\mathrm{CDCl}_{3}$ ) data, see Table 2; HRESIMS $\mathrm{m} / \mathrm{z}$ $365.0995[\mathrm{M}+\mathrm{Na}]^{+}$(calcd for $\mathrm{C}_{19} \mathrm{H}_{18} \mathrm{NaO}_{6}, 365.0996$ ).

Pisonone G (7). Colorless oil; UV (MeOH) $\lambda_{\max }(\log \varepsilon) 241$ (0.42) nm; $274(0.81) \mathrm{nm} ;{ }^{1} \mathrm{H}$ NMR (600 MHz, $\mathrm{CDCl}_{3}$ ) and ${ }^{13} \mathrm{C}$ NMR (150 MHz, $\mathrm{CDCl}_{3}$ ) data, see Table 2; HRESIMS $\mathrm{m} / \mathrm{z}$ 313.0707 $[\mathrm{M}+\mathrm{H}]^{+}$(calcd for $\mathrm{C}_{17} \mathrm{H}_{13} \mathrm{O}_{6}, 313.0707$ ).

Pisonone $\mathbf{H}$ (8). Colorless oil; UV $(\mathrm{MeOH}) \lambda_{\max }(\log \varepsilon) 241$ (0.56) nm; $287(0.45) \mathrm{nm} ;{ }^{1} \mathrm{H}$ NMR (600 $\mathrm{MHz}, \mathrm{CDCl}_{3}$ ) and ${ }^{13} \mathrm{C}$ NMR (150 MHz, $\mathrm{CDCl}_{3}$ ) data, see Table 3; HRESIMS $\mathrm{m} / \mathrm{z}$ 313.0707 [M + H $]^{+}$(calcd for $\mathrm{C}_{17} \mathrm{H}_{13} \mathrm{O}_{6}, 313.0707$ ).

Pisonone I (9). Colorless oil; UV $(\mathrm{MeOH}) \lambda_{\max }(\log \varepsilon) 240$ (0.68) nm; $263(0.21) \mathrm{nm} ;{ }^{1} \mathrm{H}$ NMR (600 MHz, $\left.\mathrm{CDCl}_{3}\right)$ and ${ }^{13} \mathrm{C}$ NMR (150 $\mathrm{MHz}, \mathrm{CDCl}_{3}$ ) data, see Table 3; HRESIMS $\mathrm{m} / \mathrm{z}$ $329.1020[\mathrm{M}+\mathrm{H}]^{+}$(calcd for $\mathrm{C}_{18} \mathrm{H}_{17} \mathrm{O}_{6}, 329.1020$ ).

Pisonone J (10). Colorless oil; UV $(\mathrm{MeOH}) \lambda_{\max }(\log \varepsilon) 234$ (0.77) nm; 263 (0.17) nm; ${ }^{1} \mathrm{H}$ NMR (600 MHz, $\left.\mathrm{CDCl}_{3}\right)$ and ${ }^{13} \mathrm{C}$ NMR (150 MHz, $\mathrm{CDCl}_{3}$ ) data, see Table 3; HRESIMS $\mathrm{m} / \mathrm{z}$ $329.1020[\mathrm{M}+\mathrm{H}]^{+}$(calcd for $\mathrm{C}_{18} \mathrm{H}_{17} \mathrm{O}_{6}, 329.1020$ ).

\section{ECD computation section}

The absolute configurations shown as 1a/2a/3a were used as the input configuration of theoretical calculations. Firstly, a systematic conformational analysis was performed to find all possible conformers within a $3 \mathrm{kcal} \mathrm{mol}^{-1}$ energy window in the MMFF94 force field. For 3a, the 3-methoxypropen-1-yl group was replaced by vinyl group to reduce the computation. The obtained conformers were further optimized and identified as the stable conformers at the B3LYP/6-31G (d) level by the Gaussian 09 program. ${ }^{18}$ Main conformers (Boltzmann distribution $>1 \%$ ) of each compound were chosen for ECD calculations. All quantum computations are performed on an IBM cluster machine located at the High Performance Computing Center of Peking Union Medical College. The lowest 120 electronic excitations were calculated and energies, oscillator strengths, and rotational strengths (velocity) of each electronic excitation were obtained. ECD spectra were then simulated with a half-bandwidth of 0.30 or $0.40 \mathrm{eV}$. By comparison of the calculated and experimental ECD spectra, their configurations were established.

\section{Chiral-phase separation}

Compounds $\mathbf{1}$ and $\mathbf{2}$ were both separated by a chiral-phase chromatographic AS-H column $(4.6 \times 250 \mathrm{~mm}, 5 \mu \mathrm{m})$, using $n$-hexane/isopropanol $(7: 3)$ as mobile phase to yield $1 \mathrm{a}\left(t_{\mathrm{R}}=\right.$ $18.9 \mathrm{~min}, 0.4 \mathrm{mg}), 1 \mathrm{~b}\left(t_{\mathrm{R}}=24.5 \mathrm{~min}, 0.5 \mathrm{mg}\right), 2 \mathrm{a}\left(t_{\mathrm{R}}=22.8 \mathrm{~min}\right.$, $0.5 \mathrm{mg})$ and $2 \mathbf{b}\left(t_{\mathrm{R}}=30.1 \mathrm{~min}, 0.6 \mathrm{mg}\right)$, respectively. The enantiomers of $3 \mathrm{a}\left(t_{\mathrm{R}}=14.5 \mathrm{~min}, 0.5 \mathrm{mg}\right)$ and $3 \mathbf{b}\left(t_{\mathrm{R}}=16.3 \mathrm{~min}\right.$, $0.5 \mathrm{mg}$ ) were also obtained by chiral HPLC column eluted with $n$-hexane/isopropanol $(8: 2)$.

\section{NO production inhibition bioassay}

The nitrite concentration in the medium was measured as an indicator of NO production according to the Griess reaction. Briefly, RAW 264.7 cells were seeded into 96-well plates at density of $1 \times 10^{5}$ cell per well and stimulated with $1 \mu \mathrm{g} \mathrm{mL} \mathrm{mL}^{-1}$ of LPS in the presence or absence of test compounds. After incubation at $37{ }^{\circ} \mathrm{C}$ for $24 \mathrm{~h}, 100 \mu \mathrm{L}$ of cell-free supernatant was mixed with $100 \mu \mathrm{L}$ of Griess reagent containing equal volumes of $2 \%(\mathrm{w} / \mathrm{v})$ sulfanilamide in $5 \%(\mathrm{w} / \mathrm{v})$ phosphoric acid and $0.2 \%$ (w/v) of $N$-(1-naphthyl) ethylenediamine solution to determine nitrite production. Absorbance was measured in microplate reader at $540 \mathrm{~nm}$ against a calibration curve with $\mathrm{NaNO}_{2}$ standards. Experiments were performed in triplicate, and data were expressed as the mean $\pm \mathrm{SD}$ of three independent experiments. ${ }^{19,20}$

\section{Assay for cytotoxic activity}

The cytotoxic activities of compounds 1-16 against human lung adenocarcinoma strain A-549 were determined using the 3-(4,5dimethyl-2-thiazolyl)-2,5-diphenyl-2- $H$-tetrazolium bromide (MTT) assay. K562 cell viability was assessed by trypan blue exclusion test. Both A-549 and K562 cells were maintained in DMEM medium containing 10\% Fetal Bovine Serum (FBS) and $0.4 \%$ penicillin-streptomycin solution $(100 \times)$ at $37{ }^{\circ} \mathrm{C}$ under $5 \% \mathrm{CO}_{2}$. When A549 cells showed logarithmic growth, diluted them to a concentration of $1 \times 10^{4}$ cells per $\mathrm{mL}$, the diluted cell suspensions ( $200 \mu \mathrm{L}$, containing 2000 cells per well) were placed into 96-well microtiter plates and incubated at $37^{\circ} \mathrm{C}$ for $24 \mathrm{~h}$, at a $5 \% \mathrm{CO}_{2}$ atmosphere. $\mathrm{K} 562$ was prepared at a concentration of $1 \times 10^{4}$ cells per mL directly, and diluted to 96-well microtiter plates. After $72 \mathrm{~h}$ incubation, every well was added with the MTT or MTS solution and maintained for another $4 \mathrm{~h}$. Then the cells were fixed and stained with $150 \mu \mathrm{L}$ DMSO for $10 \mathrm{~min}$. The absorption was measured at $570 \mathrm{~nm}$ in an Ultra Microplate Reader (Elx 808, BIO-TEX Instruments, Inc.). ${ }^{21}$

\section{Conflicts of interest}

There are no conflicts to declare. 


\section{Acknowledgements}

This work was supported by the National Natural Science Foundation of China (No. 81502968), National Major New Drug Creation Project of China (No. 2014ZX09509001-001), and CAMS Innovation Fund for Medical Sciences (CIFMS) 201612M-3-010.

\section{Notes and references}

1 C. Lavaud, S. Beauviere, G. Massio, L. L. Men-Olivier and G. Bourdy, Phytochemistry, 1996, 43, 189-194.

2 H. T. Kuo, C. F. Peng, H. Y. Huang, C. H. Lin, I. S. Chen and I. L. Tsai, Planta Med., 2011, 77, 736-741.

3 S. Bezuidenhout Catherine, C. B. Bzuidenhoudt Barend, E. Brandt Vincent and D. Ferreira, J. Chem. Soc., Perkin Trans. 1, 1988, 1237.

4 D. S. Jang, E. J. Park, M. E. Hawthorne, J. S. Vigo, J. G. Graham, F. Cabieses, B. D. Santarsiero, A. D. Mesecar, H. H. S. Fong, R. G. Mehta, J. M. Pezzuto and A. D. Kinghorn, J. Nat. Prod., 2003, 66, 583-587.

5 K. Ma, T. Ishikawa, H. Seki, K. Furihata, H. Ueki and S. Narimatsu, Heterocycles, 2005, 65, 893-900.

6 Z. Zhang, G. M. Liu, Y. H. Wang, C. S. Li, Y. L. Ren, H. Xiao, X. J. Hao and H. P. He, Chin. Chem. Lett., 2007, 18, 297-299.

7 R. J. Yang, Y. S. Lan, Z. J. Huang, C. L. Shao, H. Liang, Z. F. Chen and J. Li, Rec. Nat. Prod., 2012, 6, 212-217.

8 G. P. Oliveira, T. M. G. Silva, C. A. Camara, A. L. B. D. Santana, M. S. A. Moreira and T. M. S. Silva, Phytochem. Lett., 2017, 22, 61-70.

9 Z. G. Liu, Z. L. Li, J. Bai, D. L. Meng, N. Li, Y. H. Pei, F. Zhao and H. M. Hua, J. Nat. Prod., 2014, 77, 792-799.

10 Z. G. Liu, Z. L. Li, J. Bai, D. L. Meng, N. Li, Y. H. Pei, F. Zhao and H. M. Hua, Bioorg. Med. Chem. Lett., 2016, 26, 1-5.

11 Y. B. Liu, X. R. Cheng, J. J. Qin, S. K. Yan, H. Z. Jin and W. D. Zhang, Chin. J. Nat. Med., 2011, 9, 115-119.

12 G. Julien, R. Tristan, C. Stephanie, P. P. Antonio, D. MarieCecile, C. C. Marie-France and M. Jean-Michel, J. Agric. Food Chem., 2017, 65, 8884-8891.
13 H. Fujinori, T. Satoshi and M. Junya, Phytochemistry, 1991, 30, 2197-2198.

14 C. F. Massaro, M. Katouli, T. Grkovic, H. Vu, R. J. Quinn, T. A. Heard, C. Carvalho, M. Manley-Harris, H. M. Wallace and P. Brooks, Fitoterapia, 2014, 95, 247-257.

15 W. S. Feng, X. W. Cao, X. K. Zheng and H. X. Kuang, Acta Pharm. Sin., 2005, 40, 443-446.

16 P. J. M. Abreu and Y. H. Liu, Fitoterapia, 2007, 78, 388-389.

17 T. I. B. Lopes, R. G. Coelho, N. C. Yoshida and N. K. Honda, Chem. Pharm. Bull., 2008, 56, 1551-1554.

18 M. J. Frisch, G. W. Trucks, H. B. Schlegel, G. E. Scuseria, M. A. Robb, J. R. Cheeseman, G. Scalmani, V. Barone, B. Mennucci, G. A. Petersson, H. Nakatsuji, M. Caricato, X. Li, H. P. Hratchian, A. F. Izmaylov, J. Bloino, G. Zheng, J. L. Sonnenberg, M. Hada, M. Ehara, K. Toyota, R. Fukuda, J. Hasegawa, M. Ishida, T. Nakajima, Y. Honda, O. Kitao, H. Nakai, T. Vreven Jr, J. A. Montgomery, J. E. Peralta, F. Ogliaro, M. Bearpark, J. J. Heyd, E. Brothers, K. N. Kudin, V. N. Staroverov, R. Kobayashi, J. Normand, K. Raghavachari, A. Rendell, J. C. Burant, S. S. Iyengar, J. Tomasi, M. Cossi, N. Rega, J. M. Millam, M. Klene, J. E. Knox, J. B. Cross, V. Bakken, C. Adamo, J. Jaramillo, R. Gomperts, R. E. Stratmann, O. Yazyev, A. J. Austin, R. Cammi, C. Pomelli, J. W. Ochterski, R. L. Martin, K. Morokuma, V. G. Zakrzewski, G. A. Voth, P. Salvador, J. J. Dannenberg, S. Dapprich, A. D. Daniels, Ö. Farkas, J. B. Foresman, J. V. Ortiz, J. Cioslowski and D. J. Fox, Gaussian 09, Rev. C 01, Gaussian, Inc., Wallingford CT, 2009.

19 J. Li, F. Zhao, M. Z. Li, L. X. Chen and F. Qiu, J. Nat. Prod., 2010, 73, 1667-1671.

20 V. M. Dirsch, H. Stuppner and A. M. Vollmar, Planta Med., 1998, 64, 423-426.

21 W. Ebrahim, A. Aly, V. Wray, A. Mándi, M. H. Teiten, F. Gaascht, B. Orlikova, M. U. Kassack, W. H. Lin, M. Diederich, T. Kurtán, A. Debbab and P. Proksch, J. Med. Chem., 2013, 56, 2991-2999. 